\title{
Social CAPITAL AND ENTREPRENEURSHIP IN A REgional CONTEXT
}

\author{
Eva Fuchsová ${ }^{1}$; Jitka Laštovková ${ }^{2}$; Michaela Jánská ${ }^{3}$ \\ Jan Evangelista Purkyně University in Ústí nad Labem, \\ The Faculty of Social and Economic Studies, \\ 1,3 Department of Economics and Management, \\ ${ }^{2}$ Department of Social Work, \\ Pasteurova 3544/1, 40096 Ústí nad Labem, Czech Republic \\ e-mail: ${ }^{1}$ eva.fuchsova@ujep.cz; ${ }^{2}$ jitka.lastovkova@ujep.cz; ${ }^{3}$ michaela.janska@ujep.cz
}

\begin{abstract}
The article is focused on the connection between the willingness to do business and individual capital in the context of the Ústí Region as an example of a disadvantaged region. Social capital is divided into bonding capital, related with family and friendship relations, and mobilizing capital, related to the instrumental solution of situations with the help of social relations. The article has used a secondary analysis of data gained thanks to a questionnaire survey, which was representative of inhabitants of the Ústí Region. The results showed that the willingness to do business was connected with mobilizing social capital, while bonding social capital did not play any role. The analysis, however, also includes other variables as the role of the social capital differs, for instance, regionally: people with a higher education are more willing to do business, and the same also applies to people declaring a willingness to leave the region. The complexity of the variables related to the low level of willingness to do business cannot be reduced to mobilizing social capital. However, it is also necessary to reflect its significant role.
\end{abstract}

\section{Keywords}

Entrepreneurship; Self-employment; Mobilizing social capital; Bonding social capital; Regional diversification.

\section{Introduction}

This article will focus on connections between the willingness to do business, the social capital of inhabitants of the Ústí Region and other factors that could influence the decision to do business in the region, which can be an economically disadvantaged market in the framework of the Czech Republic.

In terms of theory, social capital can be divided into social and individual capital. The social approach sees social capital as characteristics of a social organisation including its trustworthiness, reciprocity, norms and networks. They contribute to better efficiency of the operation of society and simplify the coordination of joint activities (Putman, 2001). Individual social capital is a personal source for an individual embedded in their social networks, which can be activated through relations in networks (Lin, 2002). These relations are activated primarily in situations when an individual feels a need to get information or strives for a shift on a social scale. This means that social capital is a competitive advantage when fulfilling personal goals. (Coleman, 1988). The individual social capital can be further divided into bonding, or interaction, capital (available social sources) and mobilisation capital, i. e. the "mobilisation" of the sources, where the first type is a constitutional part of both the individual and the social capital (Šafr \& Sedláčková, 2006). 
The term "social capital" was originally a sociological term used to describe aspects of social stratification. Currently, however, it is used in all social sciences. In terms of economic literature, social capital as a topic was introduced by Becker (1997). He considers it one part of human capital; it experiences amortisation, and its effects show a characteristic of an externality (Becker, 1997). The influence of individual social capital on an improvement in (economic) power is also researched (Foley \& O'Connor, 2013), as well as the access to tangible and intangible resources and the multiplicative effects of social capital on business (Debrulle, Maes, \& Sels, 2014). In the framework of economic discourse, it is possible to see social capital in view of know-how distribution with a focus on the information asymmetry and related opportunities for businessmen, where the main barrier for a successful appreciation of social capital and related know-how lies in distribution channels, which can be eliminated by building a diversified portfolio of social relations (Klyver, Evald, \& Hindle, 2011). In economy, social capital is approached also as a tool reducing transaction costs (Estrin, Mickiewicz, \& Stephan, 2013) and making it possible to resolve problems, contributing to the reduction of risks and simplifying the decision-making process (Bowey \& Easton, 2007).

The social capital has also been researched in the regional context. A study focused on peripheral regions in Switzerland has shown that local firms' ability to compete was significantly strengthened by their social capital. A positive impact was recorded particularly for the knowledge of the local environment and political individuals with decision-making rights (Habersetzer, Grèzes-Bürcher, \& Boschma, 2019). The existence of the social capital is a basic prerequisite for the establishment of agriculture cooperatives (Apparao, Garnevska, \& Shadbolt, 2019) and business in rural areas, however, it seems that a higher rate of the social capital does not lead to an increased business activity in more urbanized localities ( Sun et al., 2019).

Despite proliferation of approaches to social capital in economic theory, the authors agree on the basic determination of the term as an investment in social relations with an expectation of future market revenues. Questionnaires or experiments, such as Putman's social capital index (Putman, 2001), summation index ISC, generators of names and positions, and more, are usually used to measure the individual social capital.

However, professional papers also describe other determinants for business activities. The most frequent ones include the unemployment rate (Apergis \& Payne, 2016), the business cycle (Scholman, van Stel, \& Thurik, 2015), the interest rate development (Chowdhury, Desai, \& Audretsch, 2018), or combinations of some of the above-mentioned factors. Foreign direct investments and the business environment described, for instance, by the economic freedom index or the number of administrative operations necessary for the establishment of a business also play an important role in starting a business. The further growth of a company is significantly influenced by circumstances of its establishment, i.e. if it was established due to need (in a situation when employment was not an option) or due to an identified opportunity, where the latter is a stimulus for greater expansion (Dvouletý, 2018), (Farlie \& Fossen, 2018).

When researching the influence of social capital on the willingness to do business, it is also necessary to reflect the factors that could have influence on the regional level, i.e. the rate of unemployment, the volume of foreign direct investments and the share of people already doing business. The Ústí Region is the fifth most populated region in the Czech Republic, thanks to the total number of 820,789 inhabitants. The unemployment rate is among the highest, currently at $4.7 \%$ (the national average reaches $2 \%$ ) and there is 1.8 applicants per one available job. It is characteristic for the Ústí Region that people frequently move to Prague and the Central Bohemia Region. There is also a higher rate of internal migration activity in the region due to the geographic settlement patterns. However, the overall 
migration balance was positive in the last two years as it was improved thanks to the positive foreign balance of migration. The number of inhabitants, however, decreases due to the negative population growth (CZSO, 2018).

The foreign direct investment is only very loosely integrated in the Ústí Region's economy, as only $2.4 \%$ is allocated for the Ústí Region. This also impacts the slow rate of upgrading current production capacities. The register of economic entities for the Ústí region showed 176,111 entities as of the end of last year. This figure included 139,325 self-employed people. This was a below-average value compared to the national average. The share of selfemployed people of the total number of economically active people reached only slightly below-average values within the Czech Republic. Only nearly 50\% of the registered people really execute activities as self-employed persons (Bisnode, 2017), and the number of active entrepreneurs has been gradually decreasing since 2013. Compared to the current period, the number of entrepreneurs was 6.5 percentage points up in the years 2009 - 2012. The educational structure in the region does not reach the average for the Czech Republic, and primarily, the share of people with a university degree lags behind the national average by 7 percentage points (the year 2017). In terms of business in the Czech Republic, men show a significantly higher share compared to women, and there are two male entrepreneurs per one female. This proportion is more favourable for women in the Ústí Region (CZSO, 2018).

\section{$1 \quad$ Methods of Research}

The goal of the research is to identify the role of individual social capital in relation to the willingness to do business and uncover relations tied to the decision either to do business or to consider business activities. With regard to the character of required results, the authors used the possibility of a secondary analysis of data received in the framework of the survey Development Potential of the Ústí Region executed on a sample of 1,362 respondents. It was a quota sampling among inhabitants of the Ústí Region aged $20-70$ years. Quotas determined variables: age, gender, education, economic activity, the size of a municipality and the structural division of a region. The sample is representative, and it is thus possible to generalise the results of the questionnaire survey to all inhabitants of the Ústí Region. The data was collected in March and April 2018 by face-to-face structured interviews (nonstandardised questionnaire). The questionnaire was of an omnibus survey nature. However, only questions focused on the willingness to do business and the dimensions of the individual social capital were intentionally chosen for the purpose of researching the influence of the social capital on business.

The individual social capital in this research was operationalized on two levels - its bonding form as relations to family and friends and faith in help from them and the mobilisation form as instrumental possibilities of help in important situations.

The data were processed with the software SPSS. The authors used exploratory factor analysis and then created summation indices and used multinomial logistic regression.

\section{$2 \quad$ Results of the Research}

To be able to deal with the problem of the willingness to do business in the context of social capital and other variables, it is necessary to mention how business activity or the consideration of being involved in some kind of business is distributed across the population. More than two thirds of people (68\%) completely reject the idea. $8 \%$ of respondents actually do or did business, and $9 \%$ of the respondents have admitted considering doing business (categories I seriously considered that and Sometimes I think that were merged). A total of 
$15 \%$ of respondents have chosen the answer It came to my mind, however, I have not considered it seriously.

Social capital, measured as a rate of consent with statements characterising particular shapes of social relations and networks, after the factor analysis application really confirmed the logic of the division to two kinds of social capital. The first factor is formed by parts connected with the instrumental involvement of social relations when solving different life situations and problems. It represents mobilizing social capital. The second factor connects parts of the bonding part of the social capital (relations among relatives and friends).

Summation indices were used in the framework of particular factors (the suitability of their use was verified by Cronbach's alpha), and mobilizing social capital was divided into strong ("I have always or nearly always someone to turn to"), medium, weak, or none ("I have no one to turn to in the given situation"). The bonding family capital reached different values in absolute figures, and all respondents have shown at least some, so the authors used a different labelling - above average, average, and below-average.

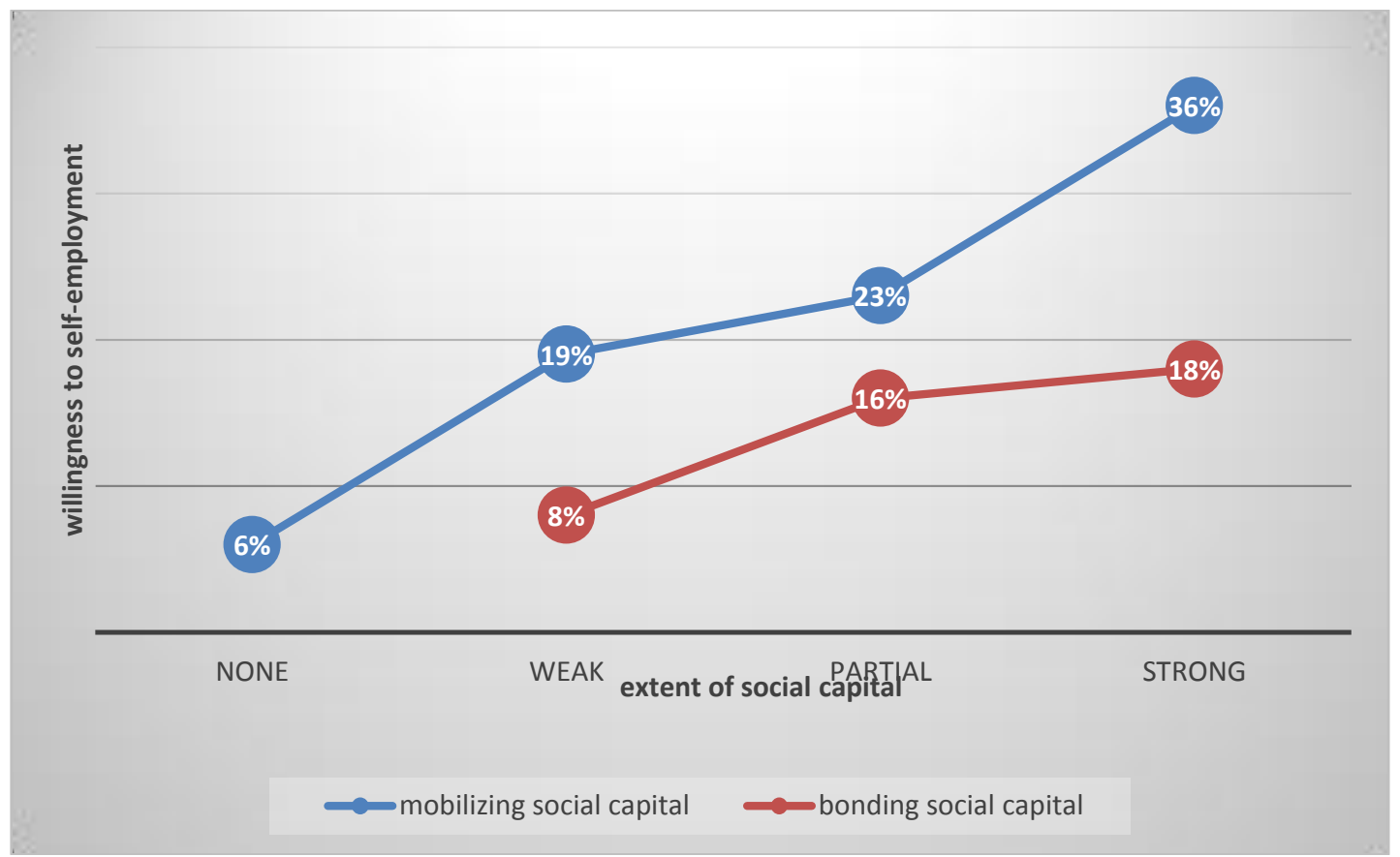

Source: authors' own calculations

Fig. 1: Willingness to do business depending on social capital

Such adjusted social capital was put in relation with the willingness to do business or to consider it, as monitored in the questionnaire. When involving particular parts or both factors, the influence of the bonding social capital was insignificant. However, it was possible to see a statistically significant ( $p$-value 0.00 ) relation with the mobilizing capital. Figure 1 shows that the higher the value of the mobilisation social capital is, the more frequently respondents are willing to consider doing business. The value of the correlation coefficient reaches 0.2 , i.e. a medium strength of relation. 


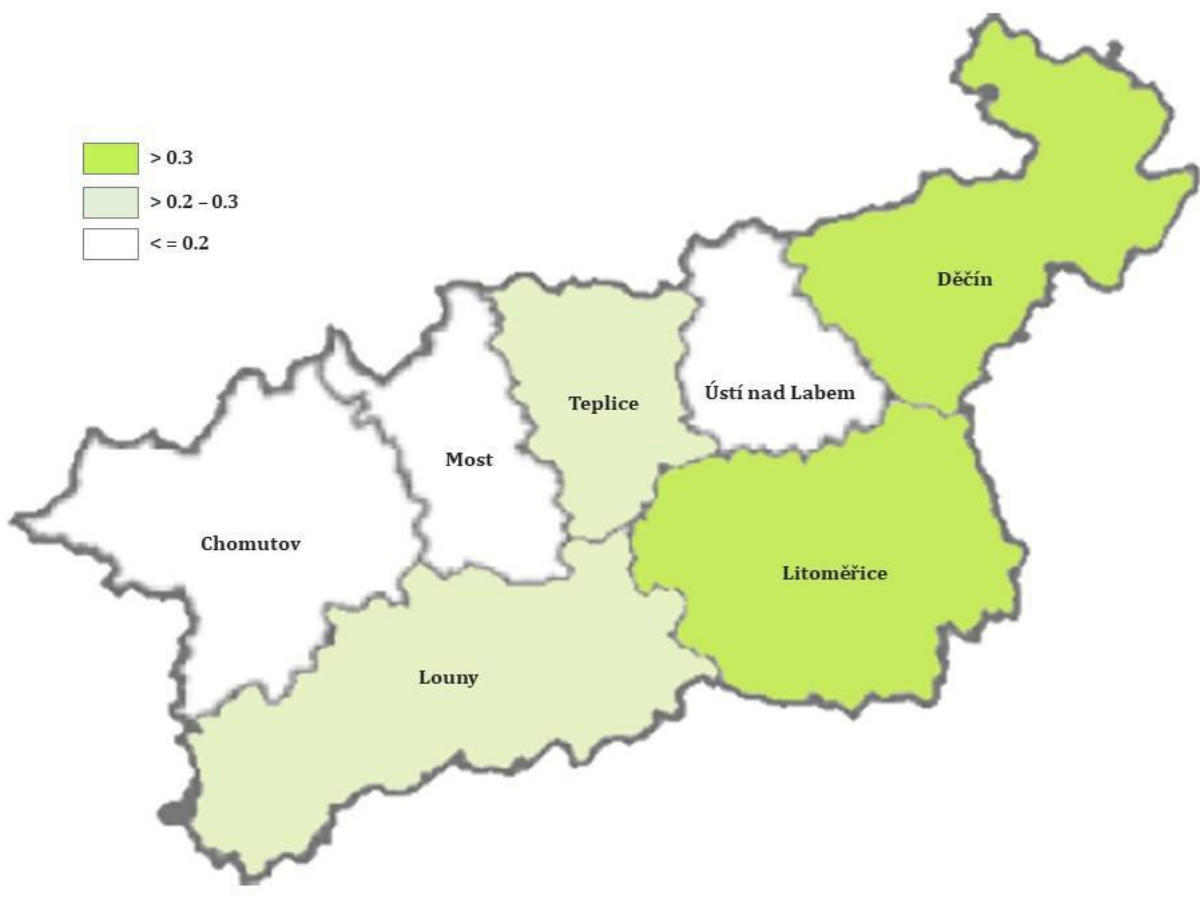

Source: authors' own calculations

Fig. 2: Relation of the mobilizing social capital with the willingness to do business in particular districts of the Usti Region (value of correlation coefficient)

The survey also showed that the influence of the mobilizing social capital on the willingness to do business was different in particular districts (see Figure 2). The correlation shows the highest figures in the districts of Litoměřice and Děčín, where the Kendall's tau coefficient exceeds 0.3, so the correlation is medium high. Each of the districts has a different character of infrastructure. The district of Litoměrice is close to Prague and shows a high development potential, while the district of Děčín has a character of social and regional exclusion (poor infrastructure, low population density). Mobilizing social capital has different roles. It is rather a necessity and expression of a higher level of control over one's economic situation in the case of the district of Děčín, while in the district of Litoměřice it is rather about the perception of a competitive advantage related to the geographic proximity of the economic centre. On the other hand, it is apparent that there is practically no individual social capital in districts characterised by large industrial enterprises and opportunities for employees, such as in Ústí nad Labem, Most and Chomutov. People decided to do business based on different factors there (Kendall's tau coefficient at 0.1 ).

Additional variables influence the process of making decisions about doing business. A statistical significance (p-value 0.00) was, for instance, registered for the relation with considerations about moving out of the region, which could be a statement about flexibility and also personal dissatisfaction with the situation in the region by respondents mentioning a higher willingness to do business.

A multinomial logistic regression was processed in relation to considerations about what other influences enter into the process of making decision about doing business. It included, as independent variables, not only social capital, but also gender, level of education, involvement in the local politics, size of municipality and region. This also proved that bonding social capital does not relate to making decisions about doing business nor to the size of a municipality. Neither involvement in local politics nor the gender of respondents have proven a relation with the willingness to do business, even though in terms of already active entrepreneurs, the share of male and female entrepreneurs is significantly uneven with 
a significant dominance of men. The category of education plays its role; more educated people, who show also a higher mobilizing social capital, consider doing business more often. In the case of the mobilizing social capital, it was necessary to adjust the effect of the category I already do or did business first, as the mobilizing social capital can be either the cause or the result of the activity. However, it is possible to find a higher rate of social capital also among those rejecting the idea, so it is possible to talk about a correlation.

\section{Discussion}

All executed statistical analyses very convincingly prove the fact that social capital is divided into two completely independent parts in the case of the willingness to do business. They are bonding social capital, whose influence can be completely ignored in this regard, and mobilizing social capital, which is, on the other hand, very important in the process of decision-making concerning business activities. This can be interpreted as the main influence of the activity of individuals, contrary to their social status determined by their origin. The role of mobilizing capital can be different, as it is shown, for instance, by the regional diversification. However, it is without doubt that "useful acquaintances" in different fields of life unquestionably strengthen the willingness to do business.

A higher willingness to do business in the district of Děčín provides evidence of a relation with factors other than social capital. The greater willingness to do business in the district of Děčín is caused rather by structural causes related with the region than by the rate of social capital. The results also indicate that a low level of willingness to do business is also influenced by the current favourable situation in the labour market. Even though the unemployment rate in the Ústí Region is more than two times higher than the national average, it is still at its long-term low. Business is thus perceived as an alternative to a more preferred employment, and people are not as interested in self-employment in the environment of a higher offer of employment opportunities. This also explains the fact of why many business entities do not grow, because business caused by "need" does not have such growth potential, contrary to the use of opportunities on the market, as it has also been proven by other papers (Dvouletý, 2018).

The fact that doing business is most often considered by those thinking about leaving the region can be interpreted on two levels. It can be either individual potential including flexibility, a will for a change on any level of life, or maybe dissatisfaction with the conditions of life in the region, which is more visible in more self-confident and independent respondents. Or it can be outer, socio-economic, factors, i.e. that conditions for business in the region are not considered favourable (for instance, due to lower foreign direct investments), or do not reflect the change of the business environment, whose relation with a particular locality decreases and makes geographic flexibility possible for entrepreneurs (for instance in relation with the development of online business).

\section{Conclusion}

Even though the business segment has an important position in the Ústí Region, its role could be rather weaker in the future. There is no motivation for business activities in the situation where economic growth is followed by decreasing unemployment. It is possible to expect higher interest in doing business if the situation changes. However, the growth will be low. The remaining newly emerging enterprises based on ideas and developed social relations are threatened by a possible relocation to some other region of the Czech Republic. This could make worse the already unfavourable trend of departures of the educated population (brain drain), the level of which is currently significantly lower compared to other regions. A lower level of attractiveness of the region for foreign direct investments is a factor making the 
business activity weaker. The question is: Will the Ústí Region be able to find a way to make conditions for entrepreneurs attractive enough to prevent further outflow of economically active and self-supporting inhabitants?

\section{Acknowledgements}

Project No. 45202015 2008-45 was supported by grant within student grant competition at UJEP - Jan Evangelista Purkyně University in Ústí nad Labem.

\section{Literature}

[1] APPARAO, D.; GARNEVSKA, E.; SHADBOLT, N.: Examining commitment, heterogeneity and social capital within the membership base of agricultural cooperatives-A conceptual framework. Journal of Co-operative Organization and Management. 2019, 7(1): 42-50. DOI: 10.1016/j.jcom.2019.03.003

[2] APERGIS, N.; PAYNE, J. E.: An empirical note on entrepreneurship and unemployment. Journal of Entrepreneurship and Public Policy. 2016, 5(1): 73-81. DOI: $10.1108 / \mathrm{JEPP}-10-2015-0029$

[3] BECKER, G. S.: Teorie preferencí. Grada, Praha, 1997. ISBN 80-7169-463-0.

[4] BISNODE: Každý druhýživnostník není aktivní. [online]. 2017. [accessed 2019-04-11]. Available from WWW: https://www.bisnode.cz/o-bisnode/o-nas/novinky/kady-druhyivnostnik-neni-aktivni/

[5] BOWEY, J. L.; EASTON, G.: Net social capital processes. Journal of Business and Industrial Marketing. 2007, 22(3): 171-177. DOI: $\underline{10.1108 / 08858620710741878}$

[6] CHOWDHURY, F.; DESAI, S.; AUDRETSCH, D. B.: Entrepreneurship: An Overview. In: CHOWDHURY, F., DESAI, S. and AUDRETSCH, D. B. (authors) Corruption, Entrepreneurship, and Social Welfare. Cham: Springer, 2018. pp 23-37. DOI: $10.1007 / 978-3-319-64916-0 \_3$

[7] COLEMAN, J. S.: Social Capital in the Creation of Human Capital. American Journal of Sociology. 1988, 94: 95-120. DOI: $\underline{10.1086 / 228943}$

[8] ČSÚ: Statistický bulletin - Ústecký kraj - 1. až 4. čtvrtletí 2018. [online]. 2018. [accessed 2019-04-10]. Available from https://www.czso.cz/csu/czso/statisticky-bulletin-ustecky-kraj-1-az-4-ctvrtleti-2018

[9] DEBRULLE, J.; MAES, J.; SELS, L.: Start-up absorptive capacity: Does the owner's human and social capital matter? International Small Business Journal: Researching Entrepreneurship. 2014, 32(14): 777-801. DOI: $10.1177 / 0266242612475103$

[10] DVOULETÝ, O.: How to analyse determinants of entrepreneurship and selfemployment at the country level? A methodological contribution. Journal of Business Venturing Insights. 2018, 9: 92-99. DOI: 10.1016/j.jbvi.2018.03.002

[11] ESTRIN, S.; MICKIEWICZ, T.; STEPHAN, U.: Entrepreneurship, Social Capital, and Institutions: Social and Commercial Entrepreneurship across Nations. Entrepreneurship Theory and Practice. 2013. 37(3): 479-504. DOI: $10.1111 /$ etap.12019

[12] FARLIE, R. W.; FOSSEN, F. M.: Opportunity versus Necessity Entrepreneurship: Two Components of Business Creation. Stanford Institute for Economic Policy Research Discussion Paper No. 17-014. 2017. DOI: 10.2139/ssrn.3010267 
[13] FOLEY, D.; O'CONNOR, A. J.: Social Capital and the Networking Practices of Indigenous Entrepreneurs. Journal of Small Business Management. 2013, 51(2): 276296. DOI: $\underline{10.1111 / j \mathrm{sbm} .12017}$

[14] HABERSETZER, A.; GRÈZES-BÜRCHER, S.; BOSCHMA, R.; MAYER, H.: Enterprise-related social capital as a driver of firm growth in the periphery? Journal of Rural Studies. 2019, 65: 143-151. DOI: 10.1016/j.jrurstud.2018.10.009

[15] KLYVER, K.; EVALD, M. R.; HINDLE, K.: Social Networks and New Venture Creation: The Dark Side of Networks. In: HINDLE, K. and KLYVER, K. (editors) Handbook of Research on New Venture Creation. Edward Efdar Publishing, Massachusetts, 2011. pp 145-159. DOI: $\underline{10.4337 / 9780857933065.00015}$

[16] LIN, N.: Social Capital. Cambridge University Press, Cambridge, 2001. Online ISBN 9780511815447. DOI: $\underline{10.1017 / C B O 9780511815447}$

[17] PUTMAN, R. D.: Bowling Alone: The Collapse and Revival of American Community. In: CSCW'00 Proceedings of the 2000 ACM conference on Computer supported cooperative work. ACM, Philadelphia, Pennsylvania, USA, 2000. ISBN 1-58113-222-0. DOI: $\underline{10.1145 / 358916.361990}$

[18] SCHOLMAN, G.; van STEL, A.; THURIK, R.: The relationship among entrepreneurial activity, business cycles and economic openness. International Entrepreneurship and Management Journal. 2015, 11(2): 307-319. DOI: 10.1007/s11365-014-0340-5

[19] SUN, X. et al.: Does social capital influence small business entrepreneurship? Differences between urban and rural China. The Annals of Regional Science. 2019, 1-19. DOI: $\underline{10.1007 / \mathrm{s} 00168-019-00922-1}$

[20] ŠAFR, J.; SEDLÁČKOVÁ, M.: Sociální kapitál: Koncepty, teorie a metody měření. Sociologický ústav AV ČR, Praha, 2006. ISBN 80-7330-095-8.

Ing. Eva Fuchsová; Mgr. Jitka Laštovková, Ph.D.; Ing. Michaela Jánská, PhD. 


\section{SOCIÁLNÍ KAPITÁL A PODNIKÁNÍ V REGIONÁLNÍM KONTEXTU}

Článek je zaměřen na souvislost mezi ochotou podnikat a individuálním kapitálem v kontextu Ústeckého kraje jako př́kladu znevýhodněného regionu. Sociální kapitál se dělí na dluhopisový kapitál spojený $\mathrm{s}$ rodinnými a přátelskými vztahy a mobilizující kapitál související $\mathrm{s}$ instrumentálním řešením situací pomocí sociálních vztahů. Příspěvek využil sekundární analýzu dat získaných pomocí dotazníkového šetření, které bylo reprezentativní pro obyvatele Ústeckého kraje. Výsledky ukázaly, že ochota podnikat byla spojena s mobilizací sociálního kapitálu, zatímco propojení sociálního kapitálu nehrálo žádnou roli. Analýza však také zahrnuje další proměnné, protože role sociálního kapitálu se liší například v regionech: lidé $\mathrm{s}$ vyšším vzděláním jsou ochotni podnikat a totéž platí i pro lidi, kteří deklarovali ochotu opustit region. Komplex proměnných souvisejících s nízkou úrovní ochoty podnikat nelze omezit na mobilizaci sociálního kapitálu. Je však také nutné zohlednit jeho významnou úlohu.

\section{SOZIALES KAPITAL UND UNTERNEHMEN IN REGIONALEM KONTEXT}

Dieser Beitrag befasst sich mit dem Zusammenhang zwischen der Bereitschaft zum Unternehmen und dem individuellen Kapital im Kontext des Aussiger Bezirks (Ústecký kraj) welcher als Beispiel einer benachteiligten Region dient. Das Sozialkapital gliedert sich in Schuldscheinkapital, welches mit Familien- und Freundschaftsbeziehungen im Zusammenhang steht, und in mobilisierendes Kapital, das mit der instrumentellen Lösung der Situationen mit Hilfe sozialer Beziehungen $\mathrm{zu}$ tun hat. Der Beitrag macht sich die Sekundäranalyse der Daten zunutze, welche mit Hilfe einer Fragebogenuntersuchung eingebacht wurden. Diese Untersuchung war für die Einwohner des Aussiger Bezirks repräsentativ. Die Ergebnisse zeigen, dass die Unternehmensbereitschaft mit der Mobilisierung des sozialen Kapitals verbunden ist, wohingegen die Einbindung des sozialen Kapitals bislang keine Rolle gespielt hat. Die Analyse umfasst jedoch auch weitere Variable, da die Rolle des sozialen Kapitals in den einzelnen Regionen unterscheidet: Menschen mit einer höheren Bildung sind bereit zu unternehmen, und das Gleiche gilt für Leute, die bereit sind, die Region zu verlassen. Der Komplex der mit der niedrigen Unternehmensbereitschaft zusammenhängenden Variablen lässt sich nicht auf die Mobilisierung und das soziale Kapital beschränken. Es ist jedoch notwendig, dessen bedeutende Rolle zu berücksichtigen.

\section{KAPITAŁ SPOŁECZNY I PRZEDSIĘBIORCZOŚĆ W KONTEKŚCIE REGIONALNYM}

Artykuł poświęcony jest zależności pomiędzy chęcią prowadzenia działalności gospodarczej a indywidualnym kapitałem w kontekście samorządowego kraju usteckiego, będącego przykładem zdefaworyzowanego regionu. Kapitał społeczny dzieli się na kapitał wiążący związany z relacjami rodzinnymi i przyjacielskimi oraz kapitał mobilizujący związany z instrumentalnym rozwiązywaniem sytuacji przy pomocy więzi społecznych. W opracowaniu wykorzystano wtórną analizę danych pozyskanych w drodze badań ankietowych, które były reprezentatywne dla mieszkańców kraju usteckiego. Wyniki pokazały, że chęć prowadzenia działalności gospodarczej była związana z mobilizacją kapitału społecznego, natomiast więzi kapitału społecznego nie odgrywały żadnej roli. Analiza obejmuje także inne zmienne, ponieważ rola kapitału społecznego różni się przykładowo w regionach: ludzie z wyższym poziomem wykształcenia są bardziej chętni do prowadzenia działalności gospodarczej i to samo dotyczy osób, które deklarowały chęć do wyjechania $\mathrm{z}$ regionu. Zespół zmiennych związanych $\mathrm{z}$ niskim poziomem chęci do prowadzenia biznesu nie można ograniczyć do mobilizacji kapitału społecznego. Należy jednak uwzględnić jego ważną rolę. 